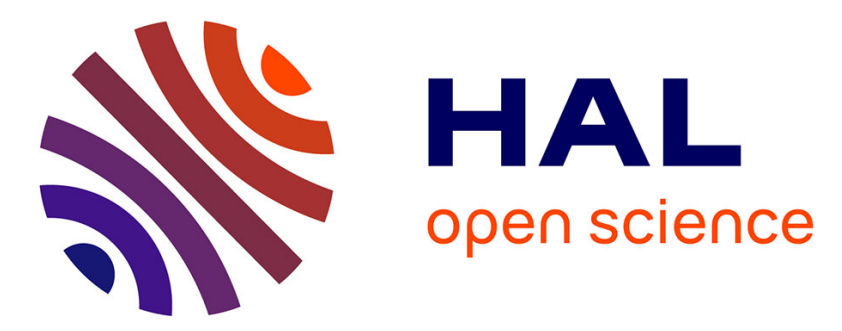

\title{
Agglomeration properties of gluten-free flours under water addition and shearing conditions
}

Loucif Chemache, Olivier Lecoq, Hacène Namoune, Driss Oulahna

\section{To cite this version:}

Loucif Chemache, Olivier Lecoq, Hacène Namoune, Driss Oulahna. Agglomeration properties of gluten-free flours under water addition and shearing conditions. LWT - Food Science and Technology, 2019, 110, pp.40-47. 10.1016/j.lwt.2019.04.058 . hal-02113719

\section{HAL Id: hal-02113719 \\ https://imt-mines-albi.hal.science/hal-02113719}

Submitted on 18 Oct 2021

HAL is a multi-disciplinary open access archive for the deposit and dissemination of scientific research documents, whether they are published or not. The documents may come from teaching and research institutions in France or abroad, or from public or private research centers.
L'archive ouverte pluridisciplinaire HAL, est destinée au dépôt et à la diffusion de documents scientifiques de niveau recherche, publiés ou non, émanant des établissements d'enseignement et de recherche français ou étrangers, des laboratoires publics ou privés. 


\title{
Agglomeration properties of gluten-free flours under water addition and shearing conditions
}

\author{
Loucif Chemache $^{\mathrm{a}, *}$, Olivier Lecoq ${ }^{\mathrm{b}}$, Hacène Namoune ${ }^{\mathrm{a}}$, Driss Oulahna ${ }^{\mathrm{b}}$ \\ ${ }^{a}$ Laboratoire de Nutrition et Technologie Alimentaire (LNTA), Institut de la Nutrition, de l'Alimentation et des Technologies Agro-Alimentaires (INATAA), Université Frères \\ Mentouri Constantine 1, Route de Ain-El-Bey, 25000, Constantine, Algeria \\ ${ }^{\mathrm{b}}$ Université de Toulouse, Mines Albi, CNRS, Centre RAPSODEE, Campus Jarlard, F.81013, Albi, France
}

\begin{abstract}
A B S T R A C T
Agglomeration properties of gluten-free cereals such as corn, manioc, amaranth, buckwheat, and quinoa flours were investigated. The different states of agglomeration were identified by the evolution of rheological properties under water addition and shearing conditions using a Caleva ${ }^{\star}$ mixer torque rheometer. The Mi-Pro ${ }^{\circ}$ highshear granulator has been used to produce wet agglomerates, which were characterized by fraction distribution, water content, density, and agglomeration yield. Results show that all samples present the same rheological characteristics: four agglomeration states are identified. The most highly developed cohesion was obtained with the amaranth flour with a mean torque of $2.4 \mathrm{~N} . \mathrm{m}$. Wet agglomeration with Mi-Pro granulator showed that all selected flours can be granulated except for manioc flour, which did not give agglomerates. Using corn flour leads to a better uniformity on the size distributions but less for amaranth, buckwheat and quinoa flours. This study shows that it is possible to agglomerate these gluten-free flours for the preparation of couscous, which may diversify the choice of couscous types for people suffering from celiac disease.
\end{abstract}

Keywords:

Corn

Manioc

Amaranth

Buckwheat

Quinoa

Wet agglomeration

Mixer Torque Rheometer

\section{Introduction}

In recent years, consumer demand has led food manufacturers to develop new healthy food products. Several gluten-free cereal products have been the subject of different studies. We can find pasta (Bouasla, Wóojtowicz \& Zidoune, 2017), bread (Pacyński, Wojtasiak, \& MildnerSzkudlarz, 2015) or cake (Marston, Khouryieh, \& Aramouni, 2016) adapted for people with celiac disease. The latter products are based on gluten-free cereals such as buckwheat, amaranth and quinoa, which have a high nutritional value and are recommended to replace conventional cereals such as wheat, barley and rye for people with gluten intolerance.

However, making new food products made from gluten-free cereals represents a major technological challenge. Gallagher, Gormley, and Arendt (2004) reported that problems can be encountered during the manufacture of gluten-free cereal based products. Indeed, gluten is the main agent for agglomeration and pasta development with durum wheat semolina or bread making with wheat flour (Sissons, Soh, \& Turner, 2007). The key question is to understand what the binding factors are during gluten-free flours agglomeration to make couscous. Generally couscous is obtained by wet agglomeration of durum wheat semolina (Chemache, Kehal, Namoune, Chaalal, \& Gagaoua, 2018).
However, many other cereals, especially gluten-free flours, can serve as raw materials for this purpose.

Currently, some gluten-free flours such as rice, manioc, buckwheat and corn are studied and used to make couscous (Benatallah, Agli, \& Zidoune, 2008; Dédédji, Ahouansou, \& Hounhouigan, 2008; Demir \& Demir, 2016; Houssou et al., 2016; Regina et al., 2015), pasta (Bouasla, Wójtowicz, \& Zidoune, 2017; Fiorda, Soares, da Silva, Grosmann, \& Souto, 2013; Gallagher et al., 2004; Islas-Rubio, Calderón de la Barca, Cabrera-Chávez, Cota-Gastélum, \& Beta, 2014), bread (Bourekoua, Benatallah, Zidoune, \& Rosell, 2016; Lazaridou, Duta, Papageorgiou, Belc, \& Biliaderis, 2007; Marston et al., 2016; Pacyński et al., 2015) and cookies (Chaiya \& Pongsawatmanit, 2011; Sindhuja, Sudha, \& Rahim, 2005). However, these cereals have been the subject of only a limited number of investigations. None of them has examined the properties required for agglomeration and the mechanisms involved during water hydration.

The objective of the present paper is to explore the possibility of agglomerating gluten-free flours (corn, manioc, amaranth, buckwheat and quinoa) suitable for the preparation of couscous grains by examining and describing their agglomeration properties. The agglomeration properties of these flours have been determined by their rheological behaviour under water addition and shearing conditions.

\footnotetext{
* Corresponding author.

E-mail addresses: chemache_loucif@yahoo.fr, chemache.loucif@umc.edu.dz (L. Chemache).
} 
Table 1

Biochemical composition of the studied flours.

\begin{tabular}{llllll}
\hline \multirow{2}{*}{ Composition (g/100 g d.m.) } & \multicolumn{5}{l}{ Flours } \\
\cline { 2 - 6 } & Corn & Manioc & Amaranth & Buckwheat & Quinoa \\
\hline Proteins & 8.50 & 0.50 & 15.50 & 12.00 & 12.80 \\
Starch & 74.00 & 88.00 & 61.50 & 70.00 & 67.50 \\
Lipids & 1.70 & 0.00 & 7.10 & 3.10 & 5.10 \\
Fibers & 4.00 & 0.50 & 9.50 & 4.10 & 6.30 \\
Ash & 0.60 & 0.01 & 0.05 & 0.02 & 0.10 \\
\hline
\end{tabular}

Rheological characteristics of the gluten-free flours and various structuration states from granule to dough formation can be identified and described by hydration rate and mixing viscosity. The wet agglomerates produced by Mi-Pro high-shear granulator were characterized by fraction distribution, water content, density, and agglomeration yield.

\section{Materials and methods}

\subsection{Raw materials}

Five gluten-free flours were used to prepare samples in triplicates: amaranth, buckwheat, corn, manioc and quinoa. Biochemical compositions of these flours are provided by the suppliers and summarized in Table 1. Amaranth and quinoa are from the French company Celnat (www.celnat.fr), corn and manioc from the French company Markal (www.markal.fr) and buckwheat from the French company Nature \& Cie (www.nature-et-cie.fr).

\subsection{Flours characterization}

Mean particle size and particle size distribution (PSD) were determined by laser diffraction using a Mastersizer 3000 with dry module Aero S (Malvern Instrument, UK) under an air pressure of $210^{5} \mathrm{~Pa}$. A refractive index of $1.570(+0.1 \mathrm{i}$ ) was used for the particles (by default use) and a refractive index of 1.000 for continuous phase (air). Results were expressed as volume percentage (\%) according to the particle size diameter $(\mu \mathrm{m})$. The particle size distributions were analysed using the Malvern 3000 software version 3.50 and characterized by the diameters $\left(\mathrm{d}_{10}, \mathrm{~d}_{50}\right.$, and $\left.\mathrm{d}_{90}\right)$ and by span $\left(\mathrm{d}_{90}-\mathrm{d}_{10}\right) / \mathrm{d}_{50}$. The criterion $\mathrm{d}_{10}\left(\mathrm{~d}_{50}\right.$, or $\mathrm{d}_{90}$ ) means that $10 \%(50 \%$ or $90 \%)$ of particles have a diameter smaller than this criterion.

The aerated bulk density $\left(\rho_{\mathrm{a}}\right)$ was measured by a graduated cylinder of $250 \mathrm{~mL}$ and defined by the ratio of the mass and the occupied volume of powder $(\mathrm{g} / \mathrm{mL})$ without settlement. Tapped bulk density $\left(\rho_{t}\right)$ was determined using density volumenometer (Erweka ${ }^{\circ}$ SVM 222). The true density $(\rho)$ of flours was determined using pycnometer with helium gas displacement (Accumulator Pyc 1330, Micromeritics') with the $10 \mathrm{~mL}$ cell. True density $(\rho)$, aerated bulk density $\left(\rho_{\mathrm{a}}\right)$ and tapped bulk density $\left(\rho_{t}\right)$ were used to calculate the ratio of densification (RD), bulk porosity $\varepsilon_{\text {(bulk) }}$ and tapped porosity $\mathcal{E}_{\text {(tapped). }}$

$R D=1-\frac{\rho_{t}}{\rho}$

$\varepsilon_{(\text {bulk })}=1-\frac{\rho_{a}}{\rho_{t}}$

$\varepsilon_{(\text {tapped })}=1-\frac{\rho_{t}}{\rho}$

Flow properties of flours were determined by calculating Carr Index (CI) and Hausner Ratio (HR) (Carr, 1965). The Carr Index, widely used as an indicator of the flowability, is evaluated using a tapped density volumenometer, after one thousand $3 \mathrm{~mm}$ height taps. In this work, the Carr Index is expressed in percent (Eq. (4)). A Carr Index smaller than 15 is associated with free-flowing powders which pack easily with gravity. On the contrary when the Carr Index is greater than 22 the untapped powder includes greater air fraction: this behaviour is typical of cohesive powders for which strong interaction forces between particles lead to less spontaneous packing under gravity (Geldart, 1973).

$$
\begin{aligned}
& \mathrm{CI}=100 \frac{\left(\rho_{t}-\rho_{a}\right)}{\rho_{t}} \\
& \mathrm{RH}=\frac{\rho_{t}}{\rho_{a}}
\end{aligned}
$$

Slope angle and mass flow of flours were measured using powder tester Erweka .

The morphology of raw flour particles and their surface details were visualized using an Environmental Scanning Electron Microscope-Field Emission Gun microscope (Philips XL30 FEG, ESEM-FEG, FEI Company). The samples were fixed on an SEM stub using double-sided adhesive tape. After acquisition, images were analysed using image software Mesurim 3.4.

\subsection{Rheological properties}

In order to determine the wet mass rheology and wet mass consistency, a mixer torque rheometer (MTR-Caleva ${ }^{\circ}$, Caleva Ltd, Dorset, England) is used as a tool for initial characterization of powder-liquid combination by carrying out the multiple liquid addition test. The rheological properties of each flour were determined as a function of water as a binder (ultra-pure water). Mixing torque is recorded with water addition at a constant shear rate to follow granule growth, from the initial granule formation phase as mentioned by Betz, Bürgin, and Leuenberger (2004), Landin, York, Cliff, Rowe, and Wigmore (1996) and Sakr, Ibrahim, Alanazi, and Sakr (2012). According to hydration rate and shear forces, the solid-liquid mixture can develop structures of different sizes and may coexist; native particles, agglomerated structures (nuclei and agglomerates), and dough pieces can be obtained (Ramachandran et al., 2008). The MTR-Caleva is comprised of an automatic binder doser and a mixing cell with rotating blades. The torque range may vary between 0 and 5 N.m. Hydration conditions are defined by the volume of water added, and the mixing time between two additions of water in relation to the weight of particles in the mixer. The mixing time between two water additions was adjusted in order to achieve homogenization. After that, the torque was measured (acquisition frequency $1 \mathrm{~Hz}$ ) at the end of each mixing time. The results are expressed as a function of the liquid to solid ratio defined as: LS ratio $=$ added liquid volume $[\mathrm{mL}$ or $\mathrm{L}] /$ initial dry powder mass $[\mathrm{g}$ or $\mathrm{kg}]$. Thus, the rheological properties of a defined weight of particles are determined from the torque variation in relation with the time and the hydration rate under given granulation conditions. At a maximum torque value, the peak represents the hydration rate $\mathrm{X}(\mathrm{L} / \mathrm{S}$ ratio) with the strongest resistance to mixing $(\mathrm{L} / \mathrm{S})_{\text {maximal }}$. This is usually considered an approximation for the optimal hydration rate (L/S ratio) for wet granulation (Kuhs, Moore, Kollamaram, Walker, \& Croker, 2017; Sakr et al., 2012). The optimum conditions for granulating of various flours in the MTR-Caleva were: $40 \mathrm{~g}$ for mass sample, $50 \mathrm{rpm}$ for mixing speed, and $1 \mathrm{~mL} / \mathrm{min}$ for the water injection rate to allow a homogeneous distribution of the hydration liquid through the bed powder during agglomeration.

\subsection{Wet agglomeration process in Mi-Pro ${ }^{\circ}$ granulator}

Wet agglomeration of the selected flours was achieved with The MiPro (Pro-C-Ept, Zelzate, Belgium) high shear mixer. A sample of $100 \mathrm{~g}$ for each flour was poured in the mixing bowl and first mixed for $60 \mathrm{~s}$ at constant impeller speed $(100 \mathrm{rpm})$ to homogenize the powder bed. The wet agglomeration was conducted at impeller speed of $500 \mathrm{rpm}$ and chopper speed of $1500 \mathrm{rpm}$. The liquid (water) addition was done at a constant rate $(2 \mathrm{~mL} / \mathrm{min})$ using a Dosimat 760 syringe pump 
(Metrohm, Berchem, Belgium). At the end, the wet agglomerate bed was mixed for $60 \mathrm{~s}$ without adding liquid (water) for maturation and dispersion.

Size distribution of the wet agglomerates was measured immediately after completing the wet agglomeration process. It was determined by sieve analysis (AS 200 digit, Retch ${ }^{\circ}$, Germany) at amplitude of 40 for $20 \mathrm{~min}$. Sieving was conducted over a column of eight metallic sieves of decreasing size (3150, 2500, 2000, 1600, 1250, 1000, 800 and $630 \mu \mathrm{m}$ ). The agglomeration yield was obtained by the ratio between the weight of wet agglomerates ranging between 630 and $2500 \mu \mathrm{m}$ and total weight of the wet agglomerates collected at the end of the agglomeration process. This yield was determined to distinguish the obtained agglomerates $(630 \leq \emptyset \leq 2500)$ from the non-agglomerated particles $(\varnothing<630 \mu \mathrm{m})$ and dough pieces $(\varnothing>2500 \mu \mathrm{m})$. The rate of dough pieces was obtained by the ratio between the weight of coarse agglomerates $(\varnothing>2500 \mu \mathrm{m})$ and total weight of the wet agglomerates collected at the end of the agglomeration process. Aerated bulk density $\left(\rho_{\mathrm{a}}\right)$ of the wet agglomerates was measured by a graduated cylinder of $50 \mathrm{~mL}$, and defined by the ratio of the mass and the occupied volume of powder $(\mathrm{g} / \mathrm{mL})$ without settlement. Tapped bulk density $\left(\rho_{t}\right)$ was determined using a density volumenometer (Erweka ${ }^{\circ}$ SVM 222). Water content ( $\mathrm{g}$ water $/ 100 \mathrm{~g}$ dry matter) of wet agglomerates was measured following the approved drying method 44-15A (AACC, 2000), i.e. at $105^{\circ} \mathrm{C}$ for $24 \mathrm{~h}$.

\subsection{Statistical analysis}

All the analyses and experimental setup were performed in triplicate. The results were expressed as the mean \pm standard deviation. One-way ANOVA was performed to determine the significant difference between the means by Tukey's HSD procedure at $\mathrm{P}<0.05$, using the statistical software Minitab 16.0 (Minitab Inc., State College, PA, USA).

\section{Results and discussion}

\subsection{Flour characteristics}

The intrinsic properties of the studied flours are summarized in Table 2. Following ANOVA at a 95\% confidence interval, the five flours can be classified according to the densification ratio RD: dense powders such as corn flour and buckwheat flour and less dense powders such as manioc, amaranth and quinoa flours. According to the Carr Index and the Hausner ratio, all powders are granular and free flowing. This was confirmed by the measurement of the slope angle and the mass flow of the flours, showing that corn flour flows more rapidly than other flours which show no significant differences in mass flow $(P<0.05)$.

Particle size distributions and particle size parameters of the flours are presented in Fig. 1 and Table 2 respectively. The results show that corn flour was the largest with $d_{10}=367 \mu \mathrm{m}, d_{50}=612 \mu \mathrm{m}$, $\mathrm{d}_{90}=1010 \mu \mathrm{m}$, and manioc flour showed the finest particle size with $d_{10}=9.08 \mu \mathrm{m}, d_{50}=16.6 \mu \mathrm{m}$ and $d_{90}=31.5 \mu \mathrm{m}$. Fig. 1 shows that the different powders have different size distributions. We can see a monomodal distribution for corn flour, a bimodal distribution for manioc and buckwheat flours, and a trimodal distribution for amaranth flour. Finally, the quinoa flour has a very wide multimodal distribution.

The shape diversity and the surface appearance of particle flours were identified by SEM, and results are depicted in Fig. 2. Results show that native particles of corn flour are irregular in shape, being either spherical or elongated (Fig. 2I.A). The particle surface is mainly composed of spherical starch grains, of between 5 and $20 \mu \mathrm{m}$ in diameter, well arranged and structured in a matrix. It is possible to also see large spaces between starch grains and some cracks (Fig. 2.II.A). Manioc flour grains are small and composed of two sizes of spherical starch grains; from 10 to $25 \mu \mathrm{m}$ diameter and from 1 to $5 \mu \mathrm{m}$ diameter (Fig. 2I.B). For amaranth flour, particles are irregular. Small spherical grains of starch were observed (between 1 and $6 \mu \mathrm{m}$ diameter) located on melted smooth structures, with some cellular structures and some bran parts (Fig. 2I.C). Buckwheat flour grains are irregular in shape (Fig. 2I.D), their surface is mainly composed of spherical starch grains from 1 to $10 \mu \mathrm{m}$ diameter with some tubular structures (Fig. 2.II.D). Fig. 2I.E shows a wide particle size and shape distribution of quinoa. Furthermore, some bran parts and diffuse structures are also observed (probably a protein matrix) in which the starch grains and leaves are stuck (Fig. 2.II.E).

\subsection{Agglomeration properties}

The agglomeration properties of the different flours used in this study are described by their rheological characteristics in relation to the hydration rate and the characterization of wet agglomerates obtained with a Mi-Pro ${ }^{\oplus}$ granulator.

\subsubsection{Influence of the hydration rate on the rheological characteristics}

The saturation rate of the agglomerates and the structural state of the mixing can be described by the rheological characteristics defined by the mean torque and the torque variation when mixing (Hancock, York, \& Rowe, 1992).

Fig. 3 depicts mean torque variations in mixer torque rheometer

Table 2

Intrinsic properties and particle size parameters of the studied flours and results of the one-way ANOVA followed by Tukey's HSD test for multiple comparisons.

\begin{tabular}{|c|c|c|c|c|c|}
\hline Flours & Corn & Manioc & Amaranth & Buckwheat & Quinoa \\
\hline Water content (g/100 g d.m.) & $12.05( \pm 0.06)^{\mathrm{a}}$ & $12.50( \pm 0.10)^{\mathrm{c}}$ & $10.40( \pm 0.61)^{\mathrm{b}}$ & $11.46( \pm 0.81)^{\mathrm{a}}$ & $8.77( \pm 0.58)^{\mathrm{ab}}$ \\
\hline Aerated bulk density $\left(\mathrm{g} / \mathrm{cm}^{3}\right)$ & $0.650( \pm 0.00)^{\mathrm{a}}$ & $0.487( \pm 0.00)^{\mathrm{c}}$ & $0.466( \pm 0.01)^{\mathrm{c}}$ & $0.585( \pm 0.00)^{\mathrm{b}}$ & $0.468( \pm 0.00)^{\mathrm{c}}$ \\
\hline Tapped bulk density $\left(\mathrm{g} / \mathrm{cm}^{3}\right)$ & $0.745( \pm 0.07)^{\mathrm{a}}$ & $0.585( \pm 0.00)^{\mathrm{b}}$ & $0.584( \pm 0.02)^{\mathrm{b}}$ & $0.722( \pm 0.02)^{\mathrm{a}}$ & $0.573( \pm 0.01)^{\mathrm{b}}$ \\
\hline True density $\left(\mathrm{g} / \mathrm{cm}^{3}\right)$ & $1.465( \pm 0.00)^{\mathrm{a}}$ & $1.515( \pm 0.00)^{\mathrm{a}}$ & $1.433( \pm 0.00)^{\mathrm{a}}$ & $1.463( \pm 0.00)^{\mathrm{a}}$ & $1.445( \pm 0.00)^{\mathrm{a}}$ \\
\hline Ratio of densification RD (\%) & $50.88( \pm 4.93)^{\mathrm{a}}$ & $38.6( \pm 0.18)^{\mathrm{b}}$ & $40.8( \pm 1.30)^{\mathrm{b}}$ & $49.4( \pm 1.41)^{\mathrm{a}}$ & $39.7( \pm 0.71)^{\mathrm{b}}$ \\
\hline Bulk porosity $\varepsilon_{\text {bulk }}(\%)$ & $55.60( \pm 0.17)^{c}$ & $67.82( \pm 0.08)^{\mathrm{a}}$ & $67.48( \pm 0.92)^{\mathrm{a}}$ & $59.98( \pm 0.82)^{\mathrm{b}}$ & $67.62( \pm 0.37)^{\mathrm{a}}$ \\
\hline Tapped porosity $\varepsilon_{\text {tapped }}(\%)$ & $49.10( \pm 4.93)^{\mathrm{b}}$ & $61.40( \pm 0.18)^{\mathrm{a}}$ & $61.72( \pm 1.30)^{\mathrm{a}}$ & $50.66( \pm 1.41)^{\mathrm{b}}$ & $60.34( \pm 0.71)^{\mathrm{a}}$ \\
\hline Slope angle $\left({ }^{\circ}\right)$ & $46.43( \pm 1.46)^{\mathrm{a}}$ & $49.90( \pm 1.01)^{\mathrm{a}}$ & $52.10( \pm 1.54)^{\mathrm{a}}$ & $50.50( \pm 2.70)^{\mathrm{a}}$ & $48.00( \pm 7.57)^{\mathrm{a}}$ \\
\hline Mass flow (g/s) & $11.39( \pm 0.01)^{\mathrm{c}}$ & $1.79( \pm 0.12)^{\mathrm{a}}$ & $1.26( \pm 0.23)^{\mathrm{a}}$ & $2.94( \pm 0.09)^{\mathrm{b}}$ & $1.78( \pm 0.52)^{\mathrm{a}}$ \\
\hline Carr Index CI & $12.75( \pm 8.21)^{\mathrm{a}}$ & $16.75( \pm 0.33)^{\mathrm{a}}$ & $20.21( \pm 1.31)^{\mathrm{a}}$ & $18.98( \pm 2.26)^{\mathrm{a}}$ & $18.32( \pm 0.54)^{\mathrm{a}}$ \\
\hline Hausner ratio $\mathrm{HR}$ & $1.15( \pm 0.11)^{\mathrm{a}}$ & $1.20( \pm 0.00)^{\mathrm{a}}$ & $1.25( \pm 0.02)^{\mathrm{a}}$ & $1.23( \pm 0.03)^{\mathrm{a}}$ & $1.22( \pm 0.01)^{\mathrm{a}}$ \\
\hline $\mathrm{d}_{50}(\mu \mathrm{m})$ & $612( \pm 11.8)^{\mathrm{a}}$ & $16.6( \pm 0.70)^{\mathrm{e}}$ & $114 \pm(5.54)^{b}$ & $80.4( \pm 0.29)^{c}$ & $57.7( \pm 1.30)^{\mathrm{d}}$ \\
\hline $\mathrm{d}_{10}(\mu \mathrm{m})$ & $367( \pm 6.51)^{\mathrm{a}}$ & $9.08( \pm 0.19)^{\mathrm{c}}$ & $20.8( \pm 0.46)^{\mathrm{b}}$ & $10.50( \pm 0.09)^{\mathrm{c}}$ & $10.40( \pm 0.07)^{\mathrm{c}}$ \\
\hline $\mathrm{d}_{90}(\mu \mathrm{m})$ & $1010( \pm 11.8)^{\mathrm{a}}$ & $31.5( \pm 3.12)^{\mathrm{e}}$ & $357.50( \pm 39.44)^{\mathrm{b}}$ & $211( \pm 5.03)^{\mathrm{d}}$ & $312( \pm 17.5)^{\mathrm{c}}$ \\
\hline $\operatorname{Span}\left[\left(\mathrm{d}_{90}-\mathrm{d}_{10}\right) / \mathrm{d}_{50}\right]$ & $1.04( \pm 0.01)^{\mathrm{e}}$ & $1.35( \pm 0.12)^{\mathrm{d}}$ & $2.98( \pm 0.26)^{\mathrm{b}}$ & $2.49( \pm 0.19)^{\mathrm{c}}$ & $5.23( \pm 0.19)^{\mathrm{a}}$ \\
\hline
\end{tabular}

Data are expressed as mean \pm standard deviation. Values in rows with the same letter were not significantly different $(\mathrm{P}<0.05)$. 


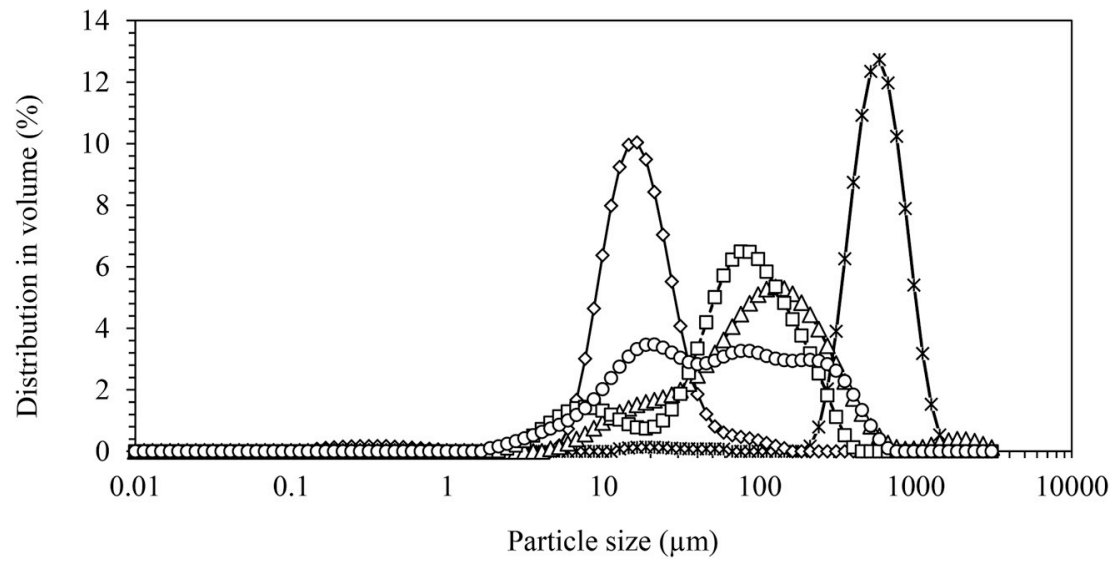

Fig. 1. Particle size distribution of the studied flours. (-* - Corn, $-\diamond-$ Manioc, $--\triangle--$ Amaranth, $-\square-$ Buckwheat, $\cdots \bigcirc \cdots$ Quinoa).

(MTR-Caleva') while mixing flours with the liquid bender. It appears that whatever the flour, the same rheological behaviours in relation to the hydration rate $(\mathrm{X})$ and the shearing rate are observed. From the evolution of the mean torque with the hydration rate, we can identify four different structural states of agglomeration delimited by hydration rates: $\mathrm{X}_{1}, \mathrm{X}_{2}$ and $\mathrm{X}_{3}$; i) $\mathrm{X}_{1}<\mathrm{X}$ : For low hydration rates, the average torque is low, and flours are considered to be dry solids. ii) $\mathrm{X}_{1}<\mathrm{X}<\mathrm{X}_{2}$ : During hydration and shearing, the structure state increases progressively with the mean torque. Aggregates begin to take shape and their size increases. The stage corresponding to the hydration rate of $\mathrm{X}_{2}$ represents funicular wetting phase. iii) $\mathrm{X}_{2}<\mathrm{X}<\mathrm{X}_{3}$ : The mean torque increases rapidly to reach a maximum value at $X_{3}$. The increase in the mixing consistency to a maximum value is due to the coalescence of aggregates by water addition up to the maximum state of aggregation, where a dough is formed. iv) $\mathrm{X}_{3}<\mathrm{X}$ : The mean torque decreases rapidly with the addition of water. At this stage, water addition dilutes the paste and its consistency decreases.

For each state and each flour investigated, we can define the hydration level and the mean torque describing the different states of agglomeration $\left(\mathrm{X}_{1}, \mathrm{X}_{2}\right.$ and $\mathrm{X}_{3}$ ) (Table 3 ). The variation of mean torque is noted with the hydration rate $\left(\mathrm{X}_{1}\right)$ of $0.500 \mathrm{~mL} / \mathrm{g}$ for corn flour and $0.350 \mathrm{~mL} / \mathrm{g}$ for manioc flour. With buckwheat and quinoa flours, hydration rate of about 0.225 and $0.250 \mathrm{~mL} / \mathrm{g}$ respectively makes it possible to give variations in the mean torque. Amaranth flour showed that hydration rate of $0.175 \mathrm{~mL} / \mathrm{g}$ was sufficient to develop the cohesion of the mixture (solid-liquid) and variation of mean torque. Until this hydration rate $\left(\mathrm{X}_{1}\right)$, the growth of the agglomerates has not yet taken place and the liquid bridges are not yet created, because the liquid is absorbed punctually on the solid particles. This phase corresponds to the nucleation state.

At the hydration rate $\mathrm{X}_{2}$, the measured mean torque on the rheometer has increased for all powders. This increase was more noticeable with quinoa flour $(1.668 \mathrm{~N} \mathrm{~m})$ at a hydration rate of $0.475 \mathrm{~mL} / \mathrm{g}$ and with amaranth flour $(0.601 \mathrm{~N} \mathrm{~m})$ at a hydration rate of $0.375 \mathrm{~mL} / \mathrm{g}$. However, with the other flours, the mean torque reached low values ranging between 0.257 and $0.325 \mathrm{~N} . \mathrm{m}$. This second stage corresponds to the beginning of the agglomeration, and the increase in the consumed power is strong and fast. The nuclei were associated with the wet native particles to form agglomerates, which grow and consolidate under shearing effect. These values of $\mathrm{X}_{2}$ were used as an hydration rates for wet agglomeration on Mi-Pro granulator.

In the third granulation stage $\left(\mathrm{X}_{3}\right)$, the rheological properties of the mixtures change and the cohesion reaches the maximum. This step can be characterized by recording the highest mean torques with amaranth at hydration rates of $0.450 \mathrm{~mL} / \mathrm{g}$, quinoa and buckwheat flours at hydration rates of $0.575 \mathrm{~mL} / \mathrm{g}$. The wet agglomeration of the manioc flour allows a cohesion development between agglomerates and the developed mean torque is $0.841 \mathrm{~N} \mathrm{~m}$ for a hydration rate of $0.650 \mathrm{~mL} / \mathrm{g}$. To achieve a maximum cohesion $(0.466 \mathrm{~N} \mathrm{~m})$ with corn flour which is the lowest one, a hydration rate of $1.250 \mathrm{~mL} / \mathrm{g}$ was required. According to Rondet, Ruiz, and Cuq (2013) and Knight (2004), by increasing water content, the agglomerates become saturated with binder and their association results in dough pieces. Agglomerates were saturated by the liquid when the hydration rate exceeded $\mathrm{X}_{3}$ and dough pieces were developed. With all the studied flours, the resistance to shear forces and the cohesiveness between the particles increase with increasing hydration rate and mixing in order to obtain the agglomerates. The same properties were observed by Hébrard et al. (2003) during the wet agglomeration of durum wheat semolina. From there, it can be noted that the studied flours can be granulated and transformed into couscous grains despite the absence of gluten in their biochemical composition. This remains possible to the extent of not exceeding the optimum hydration rate.

The possibility of wet agglomeration of the studied flours and the results obtained with MTR-Caleva granulator were examined for confirmation on the Mi-Pro granulator.

\subsubsection{Wet agglomerates characteristics}

The wet agglomeration process with Mi-Pro granulator was conducted with different flours at hydration rates $\mathrm{X}(\mathrm{L} / \mathrm{S})$ corresponding to the funicular phase determined during the MTR-Caleva granulation. Results showed that all selected flours could be granulated by wet agglomeration except for manioc flour, which did not give agglomerates in Mi-Pro granulator. Powder bed of manioc flour was caking and stuck to the mixing bowl walls during hydration. As shown in Fig. 2I.B, manioc flour is composed exclusively of fine starch grains $\left(d_{50}=16.6 \mu \mathrm{m}\right)$. The native particles of manioc flour could not ensure cohesion between them and give agglomerates. This can be due to the very low protein content $(0.50 \mathrm{~g} / 100 \mathrm{~g})$ and very small particle size $\left(d_{50}=16.6 \mu \mathrm{m}\right)$. As mentioned by Bellocq, Duri, Cuq, and Ruiz (2018), higher protein content could strengthen the structure by favouring the stickiness between the native particles. Furthermore, it should be noted that cassava flour contains no lipids and contains a very small amount of fiber $(0.50 \mathrm{~g} / 100 \mathrm{~g})$ compared to other flours. This composition could also influence the phenomenon of agglomeration.

Table 4 depicts the wet agglomeration report; water content, agglomeration yield, rate of dough pieces and densities. The results relating to the water content of the wet agglomerates show that the studied flours give wet agglomerates with different water contents. It appears that corn flour agglomerates contain the highest water content, followed by amaranth, buckwheat, and quinoa flour. This can be related to the median diameter $\left(d_{50}\right)$ of the native particles; flours with the largest median diameter give wet agglomerates with high water content. As explained by Murrieta-Pazos, Galet, Patry, Gaiani, and Scher (2014), the smallest particles (in milk powders) show a slower water diffusion coefficient. Sansano et al. (2018) observed a reduction 


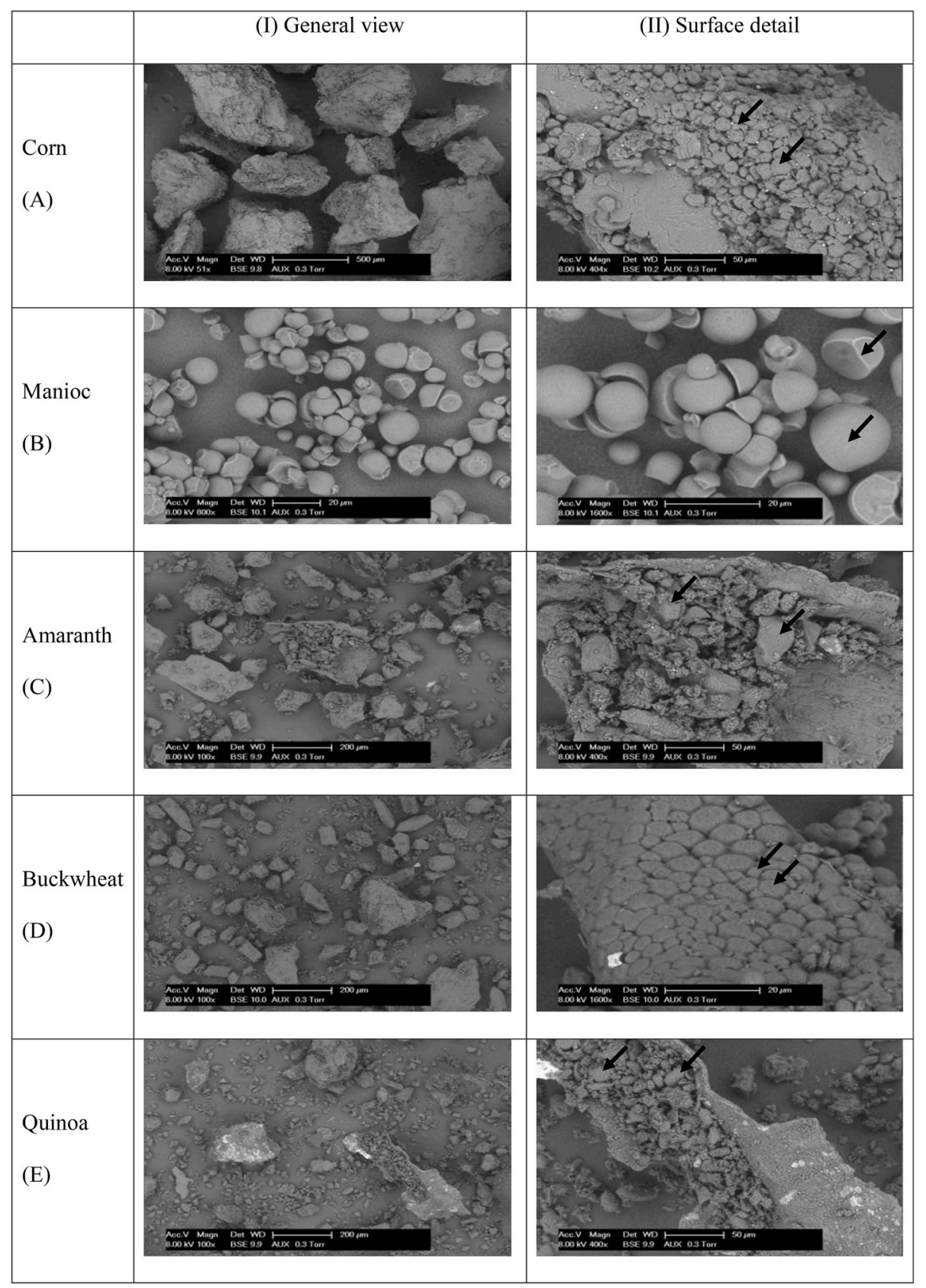

Fig. 2. Characterization of general view of particles (I) and their surface detail (II) by scanning electron microscopy for raw flours; (A) corn, (B) manioc, (C) amaranth, (D) buckwheat, and (E) quinoa. Starch grains are showed with arrows $(\rightarrow)$ in surface detail.

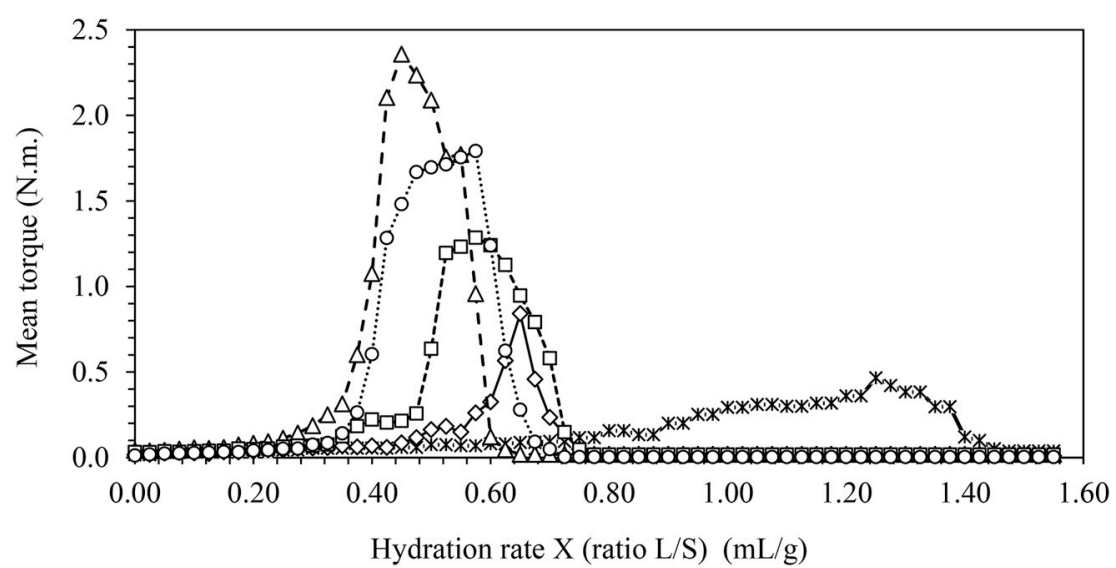

Fig. 3. Mean torque variation in mixer torque rheometer (MTR-Caleva ${ }^{\circ}$ ) during wet agglomeration of different flours. (-* - Corn, $--\triangle--$ Amaranth, $-\square-$ Buckwheat, $\cdots \bigcirc \cdots$ Quinoa). 
Table 3

Identification of the different structural states from rheological characteristics with hydration rate and results of the one-way ANOVA followed by Tukey's HSD test for multiple comparisons.

\begin{tabular}{|c|c|c|c|c|c|c|}
\hline Flours & & Corn & Manioc & Amaranth & Buckwheat & Quinoa \\
\hline \multirow[t]{3}{*}{ Hydration rate $\mathrm{L} / \mathrm{S}(\mathrm{mL} / \mathrm{g})$} & $\mathrm{X}_{1}$ & $0.500( \pm 0.02)^{\mathrm{a}}$ & $0.350( \pm 0.03)^{b}$ & $0.175( \pm 0.01)^{\mathrm{d}}$ & $0.225( \pm 0.03)^{\mathrm{cd}}$ & $0.250( \pm 0.02)^{\mathrm{c}}$ \\
\hline & $\mathrm{X}_{2}$ & $1.050( \pm 0.03)^{\mathrm{a}}$ & $0.600( \pm 0.02)^{b}$ & $0.375( \pm 0.01)^{d}$ & $0.475( \pm 0.02)^{c}$ & $0.475( \pm 0.01)^{c}$ \\
\hline & $\mathrm{X}_{3}$ & $1.250( \pm 0.05)^{\mathrm{a}}$ & $0.650( \pm 0.02)^{b}$ & $0.450( \pm 0.04)^{\mathrm{c}}$ & $0.575( \pm 0.04)^{b}$ & $0.575( \pm 0.03)^{b}$ \\
\hline \multirow{3}{*}{ Mean torque (N.m) } & $\mathrm{X}_{1}$ & $0.075( \pm 0.034)^{d}$ & $0.068( \pm 0.033)^{\mathrm{e}}$ & $0.073( \pm 0.025)^{c}$ & $0.051( \pm 0.020)^{b}$ & $0.051( \pm 0.028)^{a}$ \\
\hline & $\mathrm{X}_{2}$ & $0.310( \pm 0.105)^{d}$ & $0.325( \pm 0.059)^{c}$ & $0.601( \pm 0.060)^{b}$ & $0.257( \pm 0.069)^{\mathrm{e}}$ & $1.668( \pm 0.060)^{a}$ \\
\hline & $\mathrm{X}_{3}$ & $0.466( \pm 0.068)^{\mathrm{e}}$ & $0.841( \pm 0.040)^{d}$ & $2.357( \pm 0.056)^{a}$ & $1.285( \pm 0.232)^{c}$ & $1.791( \pm 0.203)^{b}$ \\
\hline
\end{tabular}

Data are expressed as mean \pm standard deviation. Values in rows with the same letter were not significantly different $(\mathrm{P}<0.05)$.

Table 4

Wet agglomeration report: water content, agglomeration yield, rate of dough pieces and densities and results of the one-way ANOVA followed by Tukey's HSD test for multiple comparisons.

\begin{tabular}{|c|c|c|c|c|}
\hline Flours & Corn & Amaranth & Buckwheat & Quinoa \\
\hline Water content (g/100 g d.m.) & $49.81( \pm 0.86)^{c}$ & $36.49( \pm 0.28)^{b}$ & $35.52( \pm 0.87)^{a b}$ & $34.32( \pm 0.58)^{\mathrm{a}}$ \\
\hline Agglomeration yield $(\mathrm{g} / 100 \mathrm{~g})$ & $98.33( \pm 0.22)^{d}$ & $84.84( \pm 1.11)^{\mathrm{c}}$ & $82.38( \pm 0.67)^{b}$ & $75.55( \pm 0.56)^{a}$ \\
\hline $\mathrm{d}_{50}(\mu \mathrm{m})$ & $1424,39( \pm 8.79)^{c}$ & $1549,17( \pm 12.60)^{b}$ & $1596,78( \pm 10.96)^{a}$ & $1530,01( \pm 11.52)^{b}$ \\
\hline Dough pieces $(\mathrm{g} / 100 \mathrm{~g})$ & $0.00( \pm 0.00)^{\mathrm{a}}$ & $13.32( \pm 0.74)^{\mathrm{b}}$ & $16.47( \pm 0.60)^{\mathrm{c}}$ & $20.86( \pm 0.44)^{d}$ \\
\hline Aerated bulk density $\left(\mathrm{g} / \mathrm{cm}^{3}\right)$ & $0.551( \pm 0.00)^{b}$ & $0.484( \pm 0.01)^{\mathrm{a}}$ & $0.601( \pm 0.01)^{c}$ & $0.572( \pm 0.01)^{b}$ \\
\hline Tapped bulk density $\left(\mathrm{g} / \mathrm{cm}^{3}\right)$ & $0.615( \pm 0.00)^{b}$ & $0.539( \pm 0.00)^{\mathrm{a}}$ & $0.651( \pm 0.01)^{c}$ & $0.613( \pm 0.00)^{b}$ \\
\hline
\end{tabular}

Data are expressed as mean \pm standard deviation. Values in rows with the same letter were not significantly different $(\mathrm{P}<0.05)$.
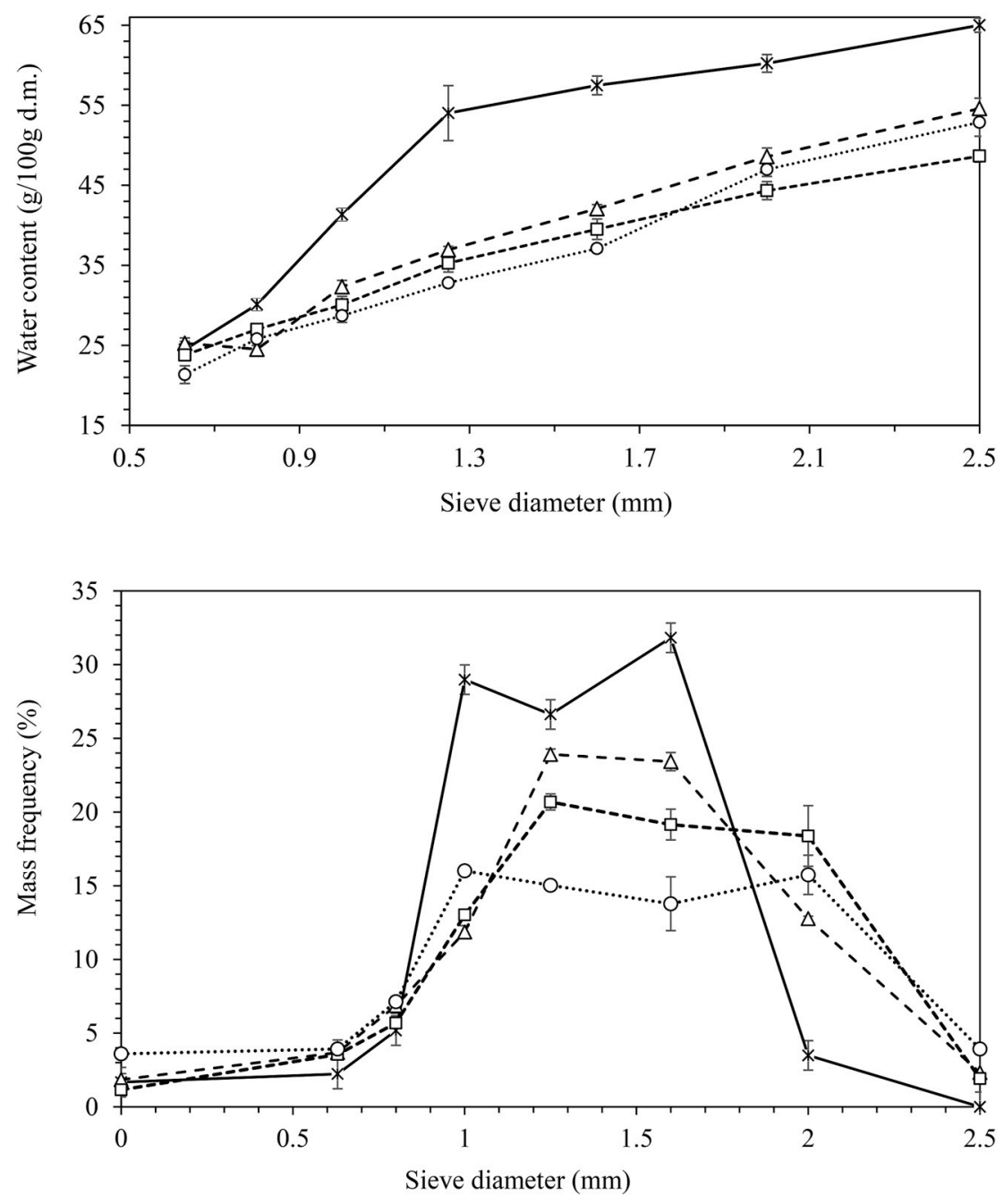

Fig. 4. Water content of the different diameters of wet agglomerates produced by the different flours on Mi-Pro granulator. ( $-*$ - Corn, $--\triangle--$ Amaranth, $-\square-$ Buckwheat, $\cdots \circ \cdots$ Quinoa).
Fig. 5. Distribution curves of the diameters of wet agglomerates produced by the different flours on Mi-Pro granulator. (-* Corn, $--\triangle--$ Amaranth, $-\square-$ Buckwheat, $\cdots \circ \cdots$ Quinoa). 
in the structure aggregation as wheat flour was replaced by rice flour in flour/water batters, as rice flour particles were smaller than wheat ones.

The water content of different size fractions constituting the wet batters of each flour was determined, and results are presented in Fig. 4. The water content of the wet fractions was positively linearly correlated with their diameter (only from $1.3 \mathrm{~mm}$ for corn flour). Several studies have shown that the increase in the median diameter of structures during wet agglomeration increases their water content (Barkouti, Delalonde, Rondet, \& Ruiz, 2014; Bellocq et al., 2018; Bellocq, Ruiz, Delaplace, Duri, \& Cuq, 2017; Rondet, Delalonde, Ruiz, \& Desfours, 2010; Saad, Barkouti, Rondet, Ruiz, \& Cuq, 2011).

The agglomeration yield changes with the used flour (Table 4). The higher amount of agglomeration yield was obtained using corn flour with $98.33 \mathrm{~g} / 100 \mathrm{~g}$, followed by amaranth flour with $84.84 \mathrm{~g} / 100 \mathrm{~g}$. The buckwheat and quinoa flours showed notable yields. Distribution curves of the diameters of the wet agglomerates are depicted in Fig. 5. It appears that wet agglomerates have a wide particle size distribution $(630-2500 \mu \mathrm{m})$. The corn agglomerates showed the smallest distribution size (from 800 to $2000 \mu \mathrm{m}$ ) probably because the corn flour has the highest median diameter $\left(\mathrm{d}_{50}=612 \mu \mathrm{m}\right)$ and the lowest span (span $=1.1$ ). Bellocq et al. (2018) reported that the decrease of the $d_{50}$ leads to an increase of the population of agglomerates. With regard to the median diameter $\left(d_{50}\right)$ of the wet agglomerates (Table 4$)$, it was found that wet agglomerates produced by buckwheat flour are the largest with $d_{50}=1596 \mu \mathrm{m}$, followed by those of quinoa and amaranth flours which have similar sizes (1530 and $1549 \mu \mathrm{m})$. At the end position, the wet agglomerates of corn flour (Table 4) showed the lower $d_{50}$ $(1424 \mu \mathrm{m})$, probably due to the poorly developed cohesion forces between native particles of corn flour, as can be seen in Fig. 3. Moreover, low protein contents of corn flour $(8.50 \mathrm{~g} / 100 \mathrm{~g})$ can limit water absorption and interaction between particles. In addition to wet agglomerates, a higher rate of dough pieces was obtained with quinoa flours $(20.86 \mathrm{~g} / 100 \mathrm{~g})$, compared to buckwheat $(16.47 \mathrm{~g} / 100 \mathrm{~g})$, amaranth $(13.32 \mathrm{~g} / 100 \mathrm{~g})$ and corn flour $(0.00 \mathrm{~g} / 100 \mathrm{~g})$. The absence of dough pieces after wet agglomeration with corn flour may be due to the absence of fine particles, its monomodal distribution and lower value of span (1.04). This could probably limit the reactivity and dissolution of flour compounds (starch and proteins) which leads to gelatinization and therefore the formation of dough matrices. Galiba, Waniska, Rooney, and Miller (1988) reported that water absorption index increased with smaller flour particle size and the coarser flour fractions had significantly less starch gelatinization than finer fractions. The aerated and tapped densities were measured for each wet mass. We can note that wet agglomerates obtained from the different flours are significantly different $(\mathrm{P}<0.05)$; Wet agglomerates of buckwheat flour are denser, followed by these of quinoa, corn and finally amaranth flour.

\section{Conclusion}

This investigation of the agglomeration properties of 5 gluten-free flours (amaranth, buckwheat, corn, quinoa and manioc) indicates that all of them except manioc can be granulated and structured under water addition and mixing.

The rheological characteristics observed during water addition and shearing present the same tendency for all these flours. Under water addition and mixing, the hydrated flours agglomerate progressively and their size increases. Up to hydration $\mathrm{X}_{3}$, the imposed shear influences the coalescence of agglomerates until a paste develops and the cohesion increases up to a maximum, corresponding to saturated capillaries and a maximum torque. The highest values of the mean torque were recorded with flours having the finest particle size. Excessive hydration and shear lead to the dilution of the mixture. From the rheological characteristics of each flour studied, we can define the different mixing states of structuration: the pendular, funicular, capillary and droplet states. These specific states for each flour can be identified and described by the hydration rate and the mixing viscosity.

Wet agglomeration in Mi-Pro ${ }^{\circledR}$ granulator showed that all selected flours can be granulated by wet agglomeration except for manioc flour. It was found that the obtained agglomerates have particle sizes which correspond to that of couscous grains $(630-2000 \mu \mathrm{m})$, and the agglomeration yields were very high especially with corn $(98.33 \mathrm{~g} / 100 \mathrm{~g})$ and amaranth $(84.84 \mathrm{~g} / 100 \mathrm{~g})$ flours which have larger particle size distributions. These results may be very interesting and may allow the manufacture of gluten-free couscous grains based on new cereals, which may diversify the choice of couscous types for people suffering from celiac disease.

\section{Acknowledgements}

This research was funded by the Algerian-French cooperation program PROFAS $\mathrm{B}+$. We acknowledge the financial support of the Algerian and French Ministries of Higher Education and Scientific Research. The first author conveys special thanks to Dr. Mohammed Gagaoua (INRA-Auvergne-Rhône-Alpes, Theix, France) for proofreading and scientific discussion of the paper and Miss Farida Kehal (UMC1, Algeria) for her technical help and support.

\section{References}

AACC (2000). AACC methods 44-15A. AACC international approved methods(10th ed.). St. Paul, MN, USA: American Association of Cereal Chemists.

Barkouti, A., Delalonde, M., Rondet, E., \& Ruiz, T. (2014). Structuration of wheat powder by wet agglomeration: Case of size association mechanism. Powder Technology, 252, $8-13$.

Bellocq, Bettina, Duri, A., Cuq, B., \& Ruiz, T. (2018). Impacts of the size distributions and protein contents of the native wheat powders in their structuration behaviour by wet agglomeration. Journal of Food Engineering, 219, 29-37.

Bellocq, B., Ruiz, T., Delaplace, G., Duri, A., \& Cuq, B. (2017). Screening efficiency and rolling effects of a rotating screen drum used to process wet soft agglomerates. Journal of Food Engineering, 195, 235-246.

Benatallah, Leila, Agli, Abdelnacer, \& Zidoune, Mohammed Nasreddine (2008). Glutenfree couscous preparation: Traditional procedure description and technological feasibility for three rice-leguminous supplemented formulae. Journal of Food Agriculture and Environment, 6, 105-112.

Betz, G., Bürgin, P. J., \& Leuenberger, H. (2004). Power consumption measurement and temperature recording during granulation. International Journal of Pharmaceutics, 272, 137-149.

Bouasla, A., Wójtowicz, A., \& Zidoune, M. N. (2017). Gluten-free precooked rice pasta enriched with legumes flours: Physical properties, texture, sensory attributes and microstructure. Lebensmittel-Wissenschaft und -Technologie- Food Science and Technology, 75, 569-577.

Bourekoua, H., Benatallah, L., Zidoune, M. N., \& Rosell, C. M. (2016). Developing gluten free bakery improvers by hydrothermal treatment of rice and corn flours. Lebensmittel-Wissenschaft und -Technologie- Food Science and Technology, 73, 342-350.

Carr, R. L. (1965). Evaluating flow properties of solids. Chemical Engineering, 72, 163-168.

Chaiya, B., \& Pongsawatmanit, R. (2011). Quality of batter and sponge cake prepared from wheat-tapioca flour blends. Kasetsart Journal - Natural Science, 45, 305-313.

Chemache, L., Kehal, F., Namoune, H., Chaalal, M., \& Gagaoua, M. (2018). Couscous: Ethnic making and consumption patterns in the Northeast of Algeria. Journal of Ethnic Foods, 5, 211-219.

Dédédji, M. M., Ahouansou, R., \& Hounhouigan, D. (2008). Evaluation des performances techniques d'un granuleur mécanique pour la production d'attiéké (couscous de manioc) au Bénin. Bulletin de La Recherche Agronomique Du Bénin, 61, 7-16.

Demir, M. K., \& Demir, B. (2016). Utilisation of buckwheat (Fagopyrum esculentum M.) and different legume flours in traditional couscous production in Turkey. Quality Assurance and Safety of Crops \& Foods, 8, 157-163.

Fiorda, F. A., Soares, M. S., da Silva, F. A., Grosmann, M. V. E., \& Souto, L. R. F. (2013). Microestructure, texture and colour of gluten-free pasta made with amaranth flour, cassava starch and cassava bagasse. Lebensmittel-Wissenschaft und -Technologie- Food Science and Technology, 54, 132-138.

Galiba, M., Waniska, R. D., Rooney, L. W., \& Miller, F. R. (1988). Couscous quality of sorghum with different kernel characteristics. Journal of Cereal Science, 7, 183-193.

Gallagher, E., Gormley, T. R., \& Arendt, E. K. (2004). Recent advances in the formulation of gluten-free cereal-based products. Trends in Food Science \& Technology, 15, $143-152$.

Geldart, D. (1973). Types of gas fluidization. Powder Technology, 7, 285-292.

Hancock, B. C., York, P., \& Rowe, R. C. (1992). Characterization of wet masses using a mixer torque rheometer: 2. Mixing kinetics. International Journal of Pharmaceutics, 83, $147-153$.

Hébrard, A., Oulahna, D., Galet, L., Cuq, B., Abecassis, J., \& Fages, J. (2003). Hydration properties of durum wheat semolina: Influence of particle size and temperature. Powder Technology, 130, 211-218.

Houssou, P. A. F., Padonou, S. W., Vodouhe, M. C. D. N., Djivoh, H., Dansou, V., Hotegni, 
A. B., et al. (2016). Improvement of the quality of yêkè-yêkè (corn based couscous) by its enrichment with different legumes seeds in Benin. International Journal of Innovation and Applied Studies, 16, 573-585.

Islas-Rubio, A. R., Calderón de la Barca, A. M., Cabrera-Chávez, F., Cota-Gastélum, A. G., \& Beta, T. (2014). Effect of semolina replacement with a raw:popped amaranth flour blend on cooking quality and texture of pasta. Lebensmittel-Wissenschaft und -Technologie- Food Science and Technology, 57, 217-222.

Knight, P. (2004). Challenges in granulation technology. Powder Technology, 140, $156-162$.

Kuhs, M., Moore, J., Kollamaram, G., Walker, G., \& Croker, D. (2017). Predicting optimal wet granulation parameters for extrusion-spheronisation of pharmaceutical pellets using a mixer torque rheometer. International Journal of Pharmaceutics, 517, 19-24.

Landin, M., York, P., Cliff, M. J., Rowe, R. C., \& Wigmore, A. J. (1996). Scale-up of a pharmaceutical granulation in fixed bowl mixer-granulators. International Journal of Pharmaceutics, 133, 127-131.

Lazaridou, A., Duta, D., Papageorgiou, M., Belc, N., \& Biliaderis, C. G. (2007). Effects of hydrocolloids on dough rheology and bread quality parameters in gluten-free formulations. Journal of Food Engineering, 79, 1033-1047.

Marston, K., Khouryieh, H., \& Aramouni, F. (2016). Effect of heat treatment of sorghum flour on the functional properties of gluten-free bread and cake. LebensmittelWissenschaft und -Technologie- Food Science and Technology, 65, 637-644.

Murrieta-Pazos, I., Galet, L., Patry, S., Gaiani, C., \& Scher, J. (2014). Evolution of particle structure during water sorption observed on different size fractions of durum wheat semolina. Powder Technology, 255, 66-73.

Pacyński, M., Wojtasiak, R. Z., \& Mildner-Szkudlarz, S. (2015). Improving the aroma of gluten-free bread. Lebensmittel-Wissenschaft und-Technologie- Food Science and Technology, 63, 706-713.
Ramachandran, R., Poon, J. M.-H., Sanders, C. F. W., Glaser, T., Immanuel, C. D., Doyle, F. J., et al. (2008). Experimental studies on distributions of granule size, binder content and porosity in batch drum granulation: Inferences on process modelling requirements and process sensitivities. Powder Technology, 188, 89-101.

Regina, K. E., Antoine, A. A., Fafadzi, E. A., Diawara, B., Sébastien, N. L., \& Philippe, T. (2015). Production d'attiéké (couscous à base de manioc fermenté) dans la ville d'Abidjan. European Scientific Journal, 11, 277-292.

Rondet, Eric, Delalonde, M., Ruiz, T., \& Desfours, J. P. (2010). Fractal formation description of agglomeration in low shear mixer. Chemical Engineering Journal, 164, 376-382.

Rondet, E., Ruiz, T., \& Cuq, B. (2013). Rheological and mechanical characterization of wet agglomerates processed in low shear mixer. Journal of Food Engineering, 117, 67-73.

Saad, M. M., Barkouti, A., Rondet, E., Ruiz, T., \& Cuq, B. (2011). Study of agglomeration mechanisms of food powders: Application to durum wheat semolina. Powder Technology, 208, 399-408.

Sakr, W. F., Ibrahim, M. A., Alanazi, F. K., \& Sakr, A. A. (2012). Upgrading wet granulation monitoring from hand squeeze test to mixing torque rheometry. Saudi Pharmaceutical Journal, 20, 9-19.

Sansano, M., Heredia, A., Glicerina, V., Balestra, F., Romani, S., \& Andrés, A. (2018). Influence of chitosan on thermal, microstructural and rheological properties of rice and wheat flours-based batters. LWT-Food Science and Technology, 87, 529-536.

Sindhuja, A., Sudha, M. L., \& Rahim, A. (2005). Effect of incorporation of amaranth flour on the quality of cookies. European Food Research and Technology, 221, 597-601.

Sissons, M. J., Soh, H. N., \& Turner, M. A. (2007). Role of gluten and its components in influencing durum wheat dough properties and spaghetti cooking quality. Journal of the Science of Food and Agriculture, 87, 1874-1885. 